\section{Phytochemical Characterization of Native New Mexico Hops}

\author{
Hanah T. Rheay ${ }^{1}$, Kevin Lombard ${ }^{2}$, Catherine Brewer ${ }^{1}$, \\ and F. Omar Holguin ${ }^{3}$
}

AdDITIONAL INDEX wORDs. bittering acids, brewing chemistry, essential oils, Humulus lupulus var. neomexicanus, polyphenols

Summary. Neomexicanus hops (Humulus lupulus var. neomexicanus) are receiving increased attention within the craft beer and nutraceutical industries. Characterization of bittering acids and essential oils in two neomexicanus varieties revealed wide ranges of bittering acid compositions and distinct essential oil profiles compared with 'Cascade' common hops (H. lupulus). Total phenolic content (TPC), expressed as gallic acid equivalent (GAE), in neomexicanus hops ranged from 50 to $100 \mathrm{mg} \cdot \mathrm{g}^{-1} \mathrm{GAE}$, consistently higher than published literature values for hop TPC ( 2 to $50 \mathrm{mg} \cdot \mathrm{g}^{-1} \mathrm{GAE}$ ). Results indicate that, compared with 'Cascade', neomexicanus hops have unique phytochemical characteristics, which may lead to new applications in brewing and nutraceutical fields.

C ommon hops (Humuluslupulus) used in brewing are typically of European genetics and cultivated between latitudes $45^{\circ} \mathrm{N}$ to $50^{\circ} \mathrm{N}$ (Dodds, 2017). Lesser studied, neomexicanus hops $(H$. lupulus var. neomexicanus) are native to the western United States, predominantly in the Rocky Mountain region between latitudes $32^{\circ} \mathrm{N}$ and $42^{\circ} \mathrm{N}$ (Smith et al., 2006). Neomexicanus hops are gaining interest among craft brewers and hop breeders (Bannerman, 2019; Jones, 2018). Named neomexicanus hop varieties and their

Received for publication 25 June 2020. Accepted for publication 22 Sept. 2020.

Published online 2 November 2020 .

${ }^{1}$ Department of Chemical and Materials Engineering, New Mexico State University, P.O. Box 30001 MSC 3805, Las Cruces, NM 88003

${ }^{2}$ New Mexico State University Agricultural Science Center at Farmington, P.O. Box 1018, Farmington, NM 87499

${ }^{3}$ Department of Plant and Environmental Sciences, New Mexico State University, P.O. Box 30003 MSC 3Q, Las Cruces, NM 88003

We acknowledge salary support from New Mexico Department of Agriculture Specialty Crop Block Grant Program (SCBGP) (Catalog of Federal Domestic Assistance Number 10.170; Funding Opportunity Number: United States Department of Agriculture-Agricultural Marketing ServiceSCBGP-2015) and New Mexico State University Department of Plant and Environmental Sciences (Rheay), and research support from NMSBrew.

Research is a portion of a thesis (H.T. Rheay) in partial fulfillment for the degree of Master of Science in Plant and Environmental Science.

H.T.R. is the corresponding author. E-mail: handsr@ nmsu.edu.

This is an open access article distributed under the CC BY-NC-ND license (https://creativecommons.org/ licenses/by-nc-nd/4.0/).

https://doi.org/10.21273/HORTTECH04678-20 hybrids include Amalia, Latir, Medusa (or Multihead), Neo-1, Sabro, and Zappa (CLS Farms, n.d.; Jones, 2018; Santa Fe Brewing Co., n.d.). Phytochemicals of interest include bittering acids and essential oils for their brewing properties as well as polyphenols, particularly xanthohumol, for nutraceutical properties. Study objectives were to survey neomexicanus hop cone chemistry and compare results to the chemistry of 'Cascade' common hops.

\section{Materials and methods}

Plant material. 'Multi-head' and 'Neo-l' neomexicanus hops and 'Cascade' common hops were cultivated under identical conditions at New Mexico State University Agricultural Science Center at Farmington (lat. $36.68915^{\circ} \mathrm{N}$, long. $108.31277^{\circ} \mathrm{W}$, elevation $1720 \mathrm{~m}$ ). Hops were harvested in stages when cones felt "dry and papery" and lupulin glands were dull yellow. Cones were air dried $(48 \mathrm{~h})$ and stored in vacuum-sealed bags in darkness at $0{ }^{\circ} \mathrm{C}$. Samples were ground using a food chopper (Homeleader K56016; Cixi, Zhejiang, China) before analysis.

EsSENTIAL OIL ANALYSIs. Essential oil analysis was performed according to American Society of Brewing Chemists (ASBC, St. Paul, MN) methodology (ASBC, 2008a). Ground hops (100 g) were distilled in $3 \mathrm{~L}$ of water for $4 \mathrm{~h}$, and the oils were collected in a calibrated graduated receiver. Oils were transferred into amber vials and stored in darkness at $0{ }^{\circ} \mathrm{C}$ until gas chromatography-mass spectroscopy (GC-MS) characterization.

BITTERING ACID ANALYsIs. Analysis of alpha and beta acid profiles followed ASBC (2008b) methodology. A mixture of ground hops (10 g), $20 \mathrm{~mL}$ of high-performance liquid chromatography (HPLC)-grade methanol, and $100 \mathrm{~mL}$ of diethyl ether was shaken for $30 \mathrm{~min}$; followed by the addition of $40 \mathrm{~mL}$ of $0.1 \mathrm{M}$ hydrochloric acid and continued shaking for $15 \mathrm{~min}$. The mixture was gravity separated. Supernatant $(5 \mathrm{~mL})$ was collected and added to a $50-\mathrm{mL}$ volumetric flask and brought to volume with HPLC-grade methanol. The solution was vacuum filtered through a Buchner funnel with filter paper (Grade 4; Whatman International, Maidstone, England) and transferred to an amber bottle. Quantification was performed immediately by HPLC using International Calibration Extract 4, obtained from ASBC, as an internal standard.

Polyphenol analysis. An extract was prepared from $10 \mathrm{~g}$ of hops in $250 \mathrm{~mL}$ of $45 \%$ ethanol (Xiong et al., 2006) and incubated in a water bath at $60{ }^{\circ} \mathrm{C}$ for $90 \mathrm{~min}$ (Kowalczyk et al., 2013). Samples were centrifuged after incubation. Liquid fractions were collected, vacuum filtered through a Buchner funnel lined with filter paper (Whatman Grade 4), and stored in amber bottles in darkness at $0{ }^{\circ} \mathrm{C}$. Total phenolic content (TPC) of hops extracts was determined by the Folin-Ciocalteau

\begin{tabular}{llll}
\hline $\begin{array}{l}\text { Units } \\
\text { To convert U.S. to SI, } \\
\text { multiply by }\end{array}$ & U.S. unit & SI unit & $\begin{array}{l}\text { To convert SI to U.S., } \\
\text { multiply by }\end{array}$ \\
\hline 10 & $\%$ & $\mathrm{mg} \cdot \mathrm{g}^{-1}$ & 0.1 \\
29,574 & $\mathrm{fl} \mathrm{oz}$ & $\mu \mathrm{L}$ & $3.3814 \times 10^{-5}$ \\
29.5735 & $\mathrm{fl} \mathrm{oz}$ & $\mathrm{mL}$ & 0.0338 \\
0.3048 & $\mathrm{ft}$ & $\mathrm{m}$ & 3.2808 \\
3.7854 & gal & $\mathrm{L}$ & 0.2642 \\
25.4 & inch $(\mathrm{es})$ & $\mathrm{mm}$ & 0.0394 \\
28.3495 & $\mathrm{Oz}$ & $\mathrm{g}$ & 0.0353 \\
$\left({ }^{\circ} \mathrm{F}-32\right) \div 1.8$ & ${ }^{\circ} \mathrm{F}$ & ${ }^{\circ} \mathrm{C}$ & $\left({ }^{\circ} \mathrm{C} \times 1.8\right)+32$ \\
& & & \\
\hline
\end{tabular}


Table 1. Composition of major bittering acid components, total essential oils, and total phenolic content in New Mexicogrown hops.

\begin{tabular}{|c|c|c|c|}
\hline \multirow[b]{2}{*}{ Analysis } & $\begin{array}{c}\text { 'Cascade' common } \\
\text { hops }\end{array}$ & $\begin{array}{c}\text { 'Neo-1' neomexicanus } \\
\text { hops }\end{array}$ & $\begin{array}{c}\text { 'Multi-head' } \\
\text { neomexicanus hops }\end{array}$ \\
\hline & \multicolumn{3}{|c|}{$($ mean $\pm S D)$} \\
\hline \multicolumn{4}{|l|}{ Bittering acid components $(\%)^{\mathrm{z}}$} \\
\hline cohumulone & $12.06 \pm 0.29 \mathrm{a}^{\mathrm{y}}$ & $16.08 \pm 4.86 \mathrm{a}$ & $3.47 \pm 0.64 \mathrm{~b}$ \\
\hline $\mathrm{n}+$ adcohumulone & $30.39 \pm 0.92 \mathrm{a}$ & $16.68 \pm 4.06 \mathrm{~b}$ & $3.89 \pm 0.59 \mathrm{c}$ \\
\hline colupulone & $14.54 \pm 0.16 \mathrm{a}$ & $11.45 \pm 3.43 \mathrm{a}$ & $17.72 \pm 2.70 \mathrm{a}$ \\
\hline Total beta-acids & 32.51 & 15.91 & 26.36 \\
\hline Total essential oils $(\mathrm{mL})^{\mathrm{x}, \mathrm{w}}$ & 0.75 & 0.15 & 0.15 \\
\hline $\begin{array}{l}\text { Total phenolic content }\left(\mathrm{mg} \cdot \mathrm{g}^{-1}\right. \\
\text { gallic acid equivalents })^{\mathrm{z}, \mathrm{w}}\end{array}$ & $50.08 \pm 1.59 \mathrm{a}$ & $94.29 \pm 6.05 \mathrm{~b}$ & $92.41 \pm 5.71 \mathrm{~b}$ \\
\hline
\end{tabular}

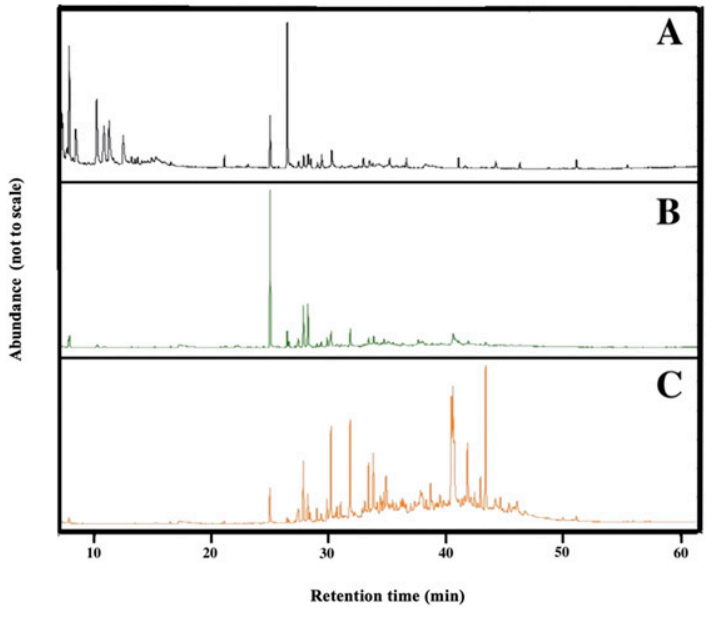

Fig. 1. Qualitative comparison of gas chromatography-mass spectroscopy chromatograms (not to scale) for New Mexico-grown hops: (A) 'Cascade' common hops, (B) 'Multi-head' neomexicanus hops, and (C) 'Neo-l' neomexicanus hops.

method, with modifications (Singleton and Rossi, 1965): $100 \mu \mathrm{L}$ of extract in $900 \mu \mathrm{L}$ deionized water $\left(\mathrm{dH}_{2} \mathrm{O}\right)$ was added to $4 \mathrm{~mL}$ of dilute $\left(\mathrm{l}: 5 \mathrm{dH}_{2} \mathrm{O}\right)$ Folin-Ciocalteau's phenol reagent (Sigma-Aldrich, St. Louis, MO). The mixture was vortexed and left to stand for $3 \mathrm{~min}$; then $5 \mathrm{~mL}$ of $7.5 \%$ sodium carbonate was added. This mixture was vortexed again, then incubated at room temperature in darkness for $60 \mathrm{~min}$. Absorbance was measured after incubation at $740 \mathrm{~nm}$ in a spectrophotometer (SpectraMax 384; Molecular Devices, San Jose, CA) and converted to GAE concentration using a standardization curve $\left(r^{2}=0.998\right)$ of gallic acid solutions prepared the same way.
Statistical analysis. Three replicates were performed for bittering acid and polyphenol analyses. Due to limited biomass material, only two replicates were obtained for essential oil distillation. Statistical analysis was performed using SAS (version 9.4; SAS Institute, Cary, NC). Results were evaluated for statistical significance at $\alpha=0.05$ using a two-way analysis of variance with Tukey's honestly significant difference post-hoc test.

\section{Results}

Compared with 'Cascade', neomexicanus hops grown under the same conditions had consistently higher TPC and lower essential oil yields (Table 1). Additionally neomexicanus essential oil profiles varied distinctly from 'Cascade'. Visual comparison of essential oil GC-MS chromatograms (Fig. 1) qualitatively indicates the presence of compounds in neomexicanus that are not present in 'Cascade'. Table 1 illustrates that neomexicanus cannot be entirely categorized as a bittering hop. 'Neo-l' has high alpha-acids, while 'Multihead' has high beta-acids. Here, 'Cascade' has an alpha:beta ratio of 1.3 , which falls within the range of reported ratios (0.64 to 1.55$)$ for the variety (Gooding Farms, n.d.).

\section{Discussion}

During centrifugation of hops: ethanol mixtures for polyphenol extraction, seeds were discovered. Low total essential oil content in neomexicanus varieties can be attributed to seed presence. Both neomexicanus varieties showed high TPC compared with 'Cascade' common hops, which had no seeds (Table 1 ).

The 2018 growing season received $126 \mathrm{~mm}$ of precipitation (79 $\mathrm{mm}$ below average), endured average temperatures of $47^{\circ} \mathrm{F}$ in January and $90{ }^{\circ} \mathrm{F}$ in June (6 and 3 ${ }^{\circ} \mathrm{F}$ above average, respectively) (O'Neill et al., 2018), and experienced spider mite infestation. Hops are generally dioecious, with female plants selected for cone production. However, these environmental stressors likely triggered a hermaphroditic response resulting in seed formation 
(Sirrine, 2017). The relationship between drought, seed presence, and high TPC is unclear; polyphenol content, however, appears to be less related to drought (Čeh et al., 2007).

\section{Conclusions}

'Multi-head' and 'Neo-l' neomexicanus hops had significantly higher TPC than published literature values for hops extracts from traditional growing regions. This supports the potential for neomexicanus hops to be a good source of xanthohumol (a subject of ongoing work). The high TPC of all the New Mexico-grown hops suggests other environmental components influencing phenolic content. If increased secondary metabolite production results from environmental factors, then this could possibly be a general characteristic of neomexicanus hops that developed under environmental stressors of New Mexico and the surrounding southwestern U.S. region (drought, high elevation, and increased solar irradiation). Data evaluated herein add to potential alternative uses for neomexicanus: as an antimicrobial agent or source for natural polyphenols. While neomexicanus hops have potential as an aroma hop, further breeding experiments to minimize hermaphroditism are needed. Neomexicanus hops examined here are unlikely to serve as a bittering hop; the high cohumulone fraction in ' $\mathrm{NeO}-\mathrm{l}$ ', would impart an undesired flavor, and the low fraction of alpha acids in 'Multi-head' make it a poor bittering candidate.

\section{Literature cited}

American Society of Brewing Chemists. 2008a. Hops method 13: Total essential oils in hops and hop pellets by steam distillation. Amer. Soc. Brewing Chem., St. Paul, MN. doi: 10.1094/asbcmoa-hops-13.

American Society of Brewing Chemists. 2008b. Hops method 14: $\alpha$-Acids and $\beta$-acids in hops and hop extracts by HPLC (International method). Amer. Soc. Brewing Chem., St. Paul, MN. doi: 10.1094/ asbcmoa-hops-14.

Bannerman, T. 2019. Native New Mexico hops are coming to a brewery near you. 20 July 2020. <https://www.newmexico. org/nmmagazine/articles/post/ neomexicanus-hops $/>$.

Čeh, B., M. Kač, I.J. Košir, and V. Abram. 2007. Relationship between xanthohumol and polyphenol content in hop leaves and hop cones with regard to water supply and cultivar. Intl. J. Mol. Sci. 8:9891000, doi: 10.3390/i8090989.

CLS Farms. n.d. Neomexicanus. 27 July 2020. <https://www.neomexicanus. $\mathrm{com} />$.

Dodds, K. 2017. Hops: A guide for new growers. 7 Nov. 2018. <https://www. dpi.nsw.gov.au/_data/assets/pdf_file/ $0007 / 712717 /$ hops-guide-for-newgrowers.pdf>.

Gooding Farms. n.d. Cascade. 26 Aug. 2020. <https://www.goodingfarms com/hop- varieties/cascade>.
Jones, K. 2018. Introducing Sabro. 20 July 2020. <http://www.washingtonbeerblog. com/introducing-sabro-a-new-highlyanticipated-hop-variety/>.

Kowalczyk, D., M. Świeca, J. Cichocka, and U. Gawlik-Dziki. 2013. The phenolic content and antioxidant activity of the aqueous and hydroalcoholic extracts of hops and their pellets. J. Inst. Brew. 119:103-110, doi: 10.1002/jib.73.

O’Neill, M.K., D. Smeal, M.M. West, S.C. Allen, and K. Djaman. 2018. Fortyeight years (1969-2016) of climatological data: NMSU ASC at Farmington, NM. New Mexico State Univ. Agr. Exp. Stn. Bul. 809. 20 Aug. 2020. <https://aces. nmsu.edu/pubs/research/weather climate/BL809.pdf>.

Santa Fe Brewing Co. n.d. Hop farm. 23 July 2020. <https://santafebrewing. com/about/hop-farm/>.

Singleton, V.L. and J.A. Rossi. 1965. Colorimetry of total phenolics with phosphomolybdic-phosphotungstic acid reagents. Amer. J. Enol. Viticult. 16:144-158.

Sirrine, R. 2017. Why are my hops producing male flowers? Michigan State Univ. Ext. 8. June 2020. <https://www. canr.msu.edu/news/why_are_my_hops_ producing_male_flowers $>$.

Smith, J.M., J.M. Oliphant, and K.E. Hummer. 2006. Plant exploration for native hop in the American southwest. Plant Genet. Resour. Newsl. 147:29-37.

Xiong, H., G. He, G. Xuan, and H. Ruan. 2006. Extraction optimization study of flavonoids from Humulus lupulus. China J. Chinese Materia Medica 31:809-811 (abstr.). 